\title{
Composition of Byzantine glasses from Umm el-Jimal, northeast Jordan: insights into glass origins and recycling
}

\author{
Khaled Al-Bashaireh* \\ Department of Archaeology, Yarmouk University, \\ Postal code 211-63, Irbid, Jordan, \\ email: khaledsm@email.arizona.edu \\ Shatha Al-Mustafa \\ Department of Archaeology, Yarmouk University, \\ Postal code 211-63, Irbid, Jordan \\ malkawi.shatha@yahoo.com \\ Ian C Freestone \\ UCL Institute of Archaeology, 31-34 Gordon Square, \\ London WC1H 0PY, UK \\ email: i.freestone@ucl.ac.uk
}

\author{
Abdel-Qader Al-Housan \\ Department of Antiquities of Al-Mafraq, \\ Al-Mafraq, Jordan \\ alhousan@yahoo.com
}

*Corresponding author 


\section{Highlights}

- Characterisation of Byzantine glass from North Jordan

- Introduction of Diagnostic Recycling Table approach

- Complementary nature of ash contamination and transition metals as indicators of recycling

- Loss of chlorine due to intensive recycling

- Byzantine glass appears heavily recycled in spite of proximity to primary furnaces of Levantine coast 
Composition of Byzantine glasses from Umm el-Jimal, northeast Jordan: insights into glass origins and recycling

Khaled Al-Bashaireh, Department of Archaeology, Yarmouk University, Postal code 21163, Irbid, Jordan, email: khaledsm@email.arizona.edu

Shatha Al-Mustafa, Department of Archaeology, Yarmouk University, Postal code 211-63, Irbid, Jordan, email: malkawi.shatha@yahoo.com

Ian C Freestone, UCL Institute of Archaeology, 31-34 Gordon Square, London WC1H 0PY. email: i.freestone@ucl.ac.uk

Abdel-Qader Al-Housan, Department of Antiquities of Al-Mafraq, Al-Mafraq, Jordan, email:alhousan@yahoo.com

\begin{abstract}
Twenty glass samples collected from four structures at Umm el-Jimal, northeast Jordan were analysed using the Electron Probe Micro-Analysis (EPMA). Except one ash-soda-lime-silica glass, all were natron-soda-lime-silica glasses of Levantine origin. Most of the glasses compositionally resemble glass from the Byzantine tank furnaces at Apollonia-Arsuf (Arsuf), but four with lower lime are closer to Umayyad period production at Bet Eli'ezer (Hadera). The paper presents diagnostic information indicating recycling in a Diagnostic Recycling Table (DRT) in which the analyses are ranked in a descending order of $\mathrm{K}_{2} \mathrm{O}$, a key contaminant in the recycling process. This allows the comparison of a range of contaminant elements and it is observed that in general glass contaminated with fuel ash components $\mathrm{K}_{2} \mathrm{O}$, $\mathrm{P}_{2} \mathrm{O}_{5}$ and $\mathrm{CaO}$ are also richer in transition metal oxides $\mathrm{CuO}, \mathrm{PbO}, \mathrm{FeO}$ and $\mathrm{MnO}$, confirming that both sets of elements are important in identifying recycled glass. Chlorine is also identified as a component modified by recycling. The results ascertain that Umm elJimal was part of a major system of glass recycling in the Byzantine period, and emphasise the importance of recycled glass in its supply, in spite of its relative proximity to the location of raw glass production on the Syro-Palestinian coast.
\end{abstract}

Key words: Glass production, Byzantine, Islamic, Jordan, Recycling, Electron microprobe 


\section{Introduction}

The archaeological site of Umm el-Jimal is located in the northeast part of Jordan near the border with Syria (Fig. 1). Ancient Umm el-Jimal is built with the black (dark grey) basalt rock of Harrat asham which covers the area to the east of the site [1]. Four (Nabataean, Roman, Byzantine and Umayyad) cultures

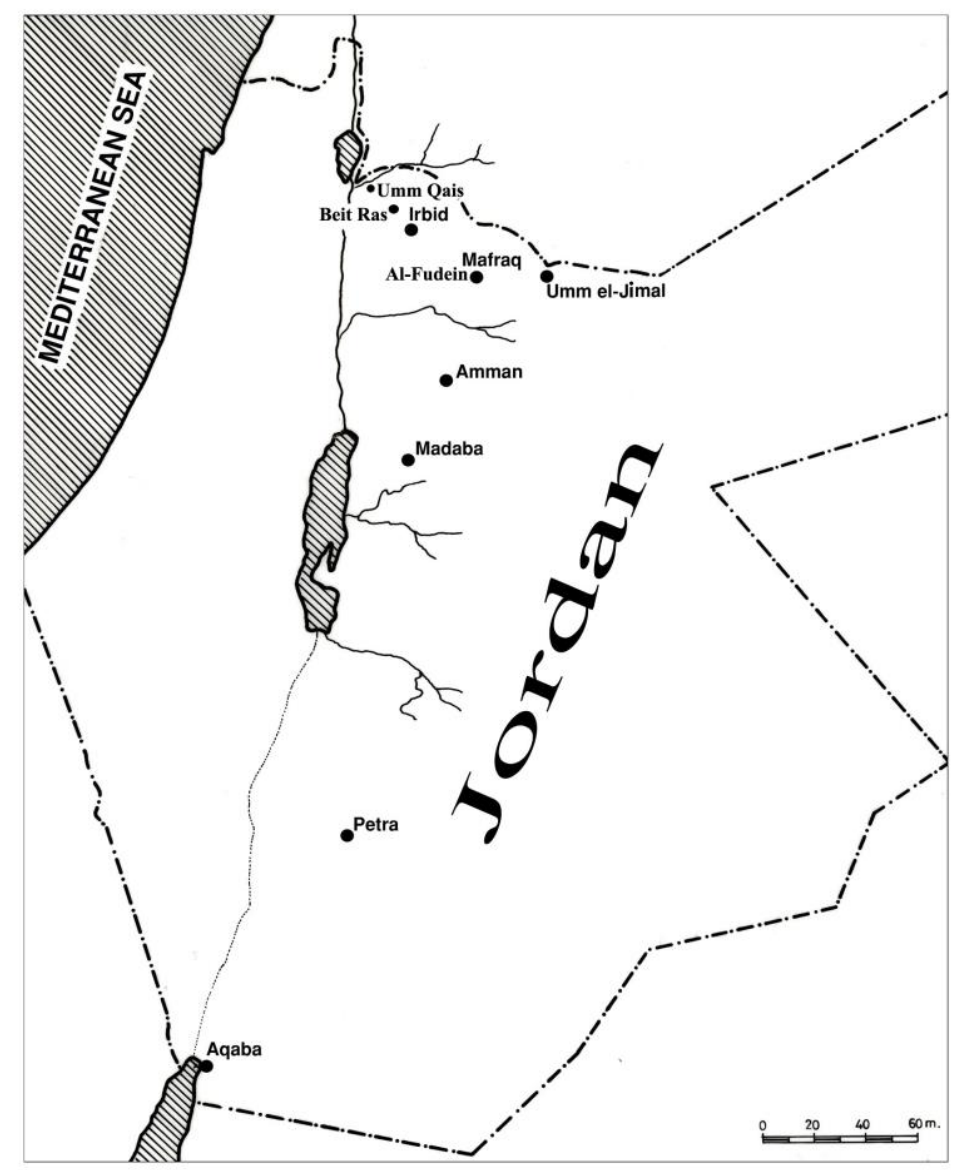

Fig. 1. Location map.

resided in the city for about 700 years and left behind them many of their structures including houses, temples, towers, churches, cemeteries, water cisterns, etc. [2,3]. These structures are located in different parts of the site while the cemeteries surround the site from three directions: the north, east and west. Excavations in the past years at three of the site's structures (the Cathedral, the Theophilus or double church and the Saint Maria church) and the north cemetery uncovered glass remains among other archaeological materials. The glasses were dated to the Roman, Roman-Byzantine and Byzantine periods depending on the pottery and coins found in the same contexts. 
Byzantine glass samples were selected for chemical analysis in this pioneer study to examine the glassmaking technology during the early (AD324-491) and late (AD491-636) Byzantine period at Umm el-Jimal and compare it to the glassmaking technology of the north Jordan area during the same period. The study explores whether the geographic location of Umm elJimal was part of a regional system of glass production and distribution during the Byzantine period.

\section{Samples and structures}

A set of twenty samples dated to the Byzantine period were selected for analysis from the four features mentioned below. One sample (sample 15) is green while the rest of the samples vary in their colors from light to bluish to olive green (Table 1 reports a brief description of the samples).

\subsection{The Cathedral}

The cathedral is the largest church at the site and located at the site's center to the south of Commodus gate. Based on an inscription found upon the fallen cap of one of the piers of the apse arch, it was dated back to the sixth century AD (AD 556). The Cathedral has a nave, two aisles, adjoining room at the east end of the north aisle and eight entries (three are at the west wall and three are at the north wall, while two are at the east wall) [2: p.183]. Glass samples were excavated from the Baptistery of the Cathedral after the removal of thick layers of around 2 meters of rubble, debris and dirt. The glass artefacts were found on the ground of the Baptistery and its niches. In addition, Byzantine and some Umayyad lamps were uncovered from the same contexts. Samples 2, 3, 10, 17 were collected from the Cathedral (Table 1).

\subsection{The Double church (or Theophilus)}

The Double church is formed of two adjacent churches separated by a wall of two joint entries; the north basilica and the south hall church. The construction of the double church was dated to the sixth century AD based on its architecture and archaeological materials found in it, although it was reused in later periods [2]. It is located at the southeastern part of the site and quite surrounded by houses. During 2012-2013 excavations at the south hall church, an inscription of Theophilus written on the mosaics was uncovered; therefore, it was also named Theophilus church. The studied glass samples were dated to the Byzantine period based on the dates of ceramics, lamps, etc. that were collected during the same excavations. 
The distinguished feature of this hall church is that its chancel screen was built with burnt bricks. Samples 4, 5, 6, 18, 19, 20 were selected from the Theophilus church (Table 1).

\subsection{Saint Maria church (chapel)}

The church is a small chapel of an entrance in its southern wall. An inscription of Agia Maria on a stone at its southern entrance was the reason to give it this name. Glass, tesserae, ceramics and lamps were uncovered during salvage excavations in 2012 and 2013 seasons. Because of the considerable amount of Umayyad ceramics found along with the Byzantine ceramics during the excavations, the chapel was dated by the site's excavator (Al-Housan) to the Late Byzantine -Early Umayyad period. Samples 7, 9, 12, 14, 15 were selected from Saint Maria church (Table 1).

\subsection{The North cemetery}

The North cemetery is located in the northeast part of the archaeological site and extends outside the city fence in certain points. It is suggested that it was used for seven centuries (1st - $7^{\text {th }}$ century AD) according to the ceramics, lamps and inscriptions uncovered from the tombs. The tombs are about $2-2.5 \mathrm{~m}$ deep, built and corbelled with basalt blocks and slabs. Some tombs have remnants of wooden coffins, where few of them were lined with bronze sheets. Most of the finds are ceramics, glass, nails, lamps, badly corroded coins and bones, wood and bronze sheets. The selected five glass samples 1, 8, 11, 13, 16 (Table 1) were collected from two tombs of a mausoleum located adjacent to the fence during a salvage excavation in 2012-2013.

\section{Methods}

Small pieces of 2-4 $\mathrm{mm}^{2}$ in size were cut from the samples, mounted in epoxy resin, ground down using silicon carbide papers to expose fresh cross sections of the glass, ground with progressively finer silicon carbide and polished with diamond pastes down to $1 \mu \mathrm{m}$ grade. Then, they were vacuum coated with a thin carbon layer in preparation for electron probe micro-analysis (EPMA) with wavelength-dispersive spectrometry (WDS). They were analysed using a JEOL JXA 8100 microprobe with three wavelength dispersive spectrometers, operated at $15 \mathrm{kV}$ accelerating potential, beam current $50 \mathrm{nA}$, working distance of $10 \mathrm{~mm}$ and rastered at a magnification of $\mathrm{x} 800$. X-rays were collected for $30 \mathrm{~s}$ on peak and 10s on each background. Standards were pure elements, oxides and minerals of known composition. Seven areas were analysed on each sample and the mean taken. Corning 
Museum Ancient Glass Standards A and B [4,5,6] were measured a number of times during the same analytical run, and the measurements compare well with the given values (Table 2). Analyses were performed at the Wolfson Archaeological Science Laboratories, UCL.

\section{Results}

\subsection{Glass origins and chronology}

Nineteen of the twenty samples are soda-lime-silica glasses (Table 2), while one sample appears to be made of plant ash glass. The 19 samples have homogeneous compositions of the Roman-Byzantine glass (averages: $71.3 \% \mathrm{SiO}_{2}, 13.7 \% \mathrm{Na}_{2} \mathrm{O}$ and $8.2 \% \mathrm{CaO}, \mathrm{Al}_{2} \mathrm{O}_{3}$ c.3.0\%). They have levels of $\mathrm{MgO}$ below $1 \%$ (from 0.42 to $0.97 \%$ ), $\mathrm{K}_{2} \mathrm{O}$ below $1.4 \%$ (from 0.44 to $1.38 \%$ ) and $\mathrm{Na}_{2} \mathrm{O}$ below $15.4 \%$ ranging from 12.61 to $15.36 \%$ which indicate that they were produced with natron as the source of flux. One sample (sample 15) has levels above $1.5 \%$ of $\mathrm{MgO}(2.91 \%)$ and $\mathrm{K}_{2} \mathrm{O}(2.75 \%)$ indicating the use of plant ash as the source of flux [7,8]. The $\mathrm{MgO}-\mathrm{K}_{2} \mathrm{O}$ values of this sample suggest the Syria-Palestine region as a provenance for this plant ash glass which has compositions with $\mathrm{K}_{2} \mathrm{O}$ and $\mathrm{MgO}$ of about 23.5\% [9: p.204]. The use of copper alloy scale as a colourant can be detected in this sample by the elevated values of copper, lead, zinc and tin compared to their low values in the rest of the glass assemblage.

It is considered that natron soda-lime-silica glass (of low magnesia and potash) was made in the southeastern Mediterranean and possibly in Europe, from the eighth century of the first millennium $\mathrm{BC}$ through to the eighth century $\mathrm{AD}$ [10: p.111,11]. Glass with the concentrations of the major components found in the present investigation was widely produced during the Byzantine and early Muslim times. On the contrary, soda-lime-silica glass of high magnesia and potash made by using plant ash reoccurred after the eighth century AD in the Levant [11]. 


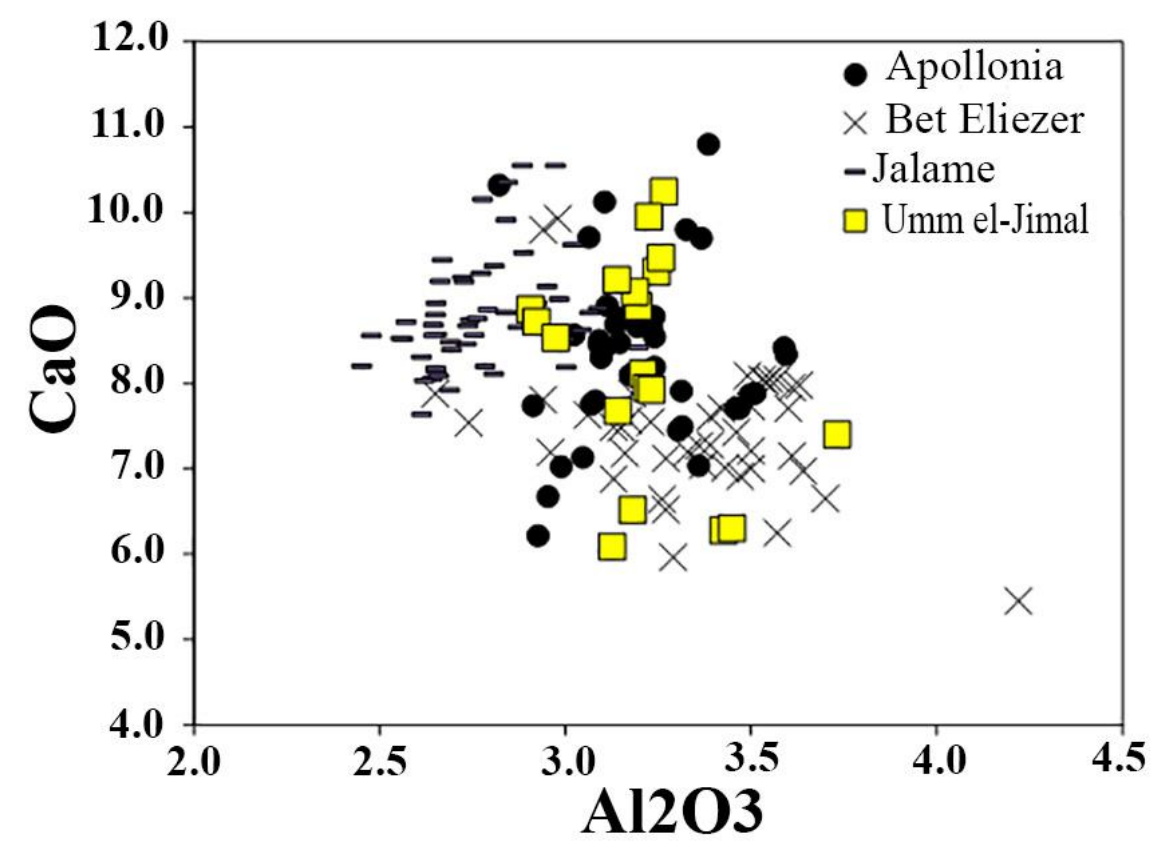

Fig. 2. Comparison of the $\mathrm{CaO}$ and $\mathrm{Al}_{2} \mathrm{O}_{3}$ contents of the Umm el-Jimal samples to Apollonia-Arsuf, Bet Eli'ezer and Jalame reference data [11,12, 13,14, unpublished]. Although there is some overlap, most of the samples are located within the Apollonia-Arsuf group while some samples are located within the Bet Eli'ezer group.

Fig. 2 and Table 2 show that the levels of lime $\mathrm{CaO}$ and alumina $\mathrm{Al}_{2} \mathrm{O}_{3}$ range from 6.08 to $10.24 \%$ and from 2.57 to $3.39 \%$. Lime and alumina values usually represent impurities of calcium carbonates and feldspars in the sand used for the production of the glass samples. The narrow range of these components in the Umm el-Jimal samples suggests the use of a common sand and this is confirmed by the strong correlation between $\mathrm{FeO}$ and $\mathrm{TiO}_{2}\left(\mathrm{R}^{2}=\right.$ 0.8757) which conforms to the trend recorded from Palestinian tank furnaces and reflects the manufacture of the glass there (Fig. 3). 


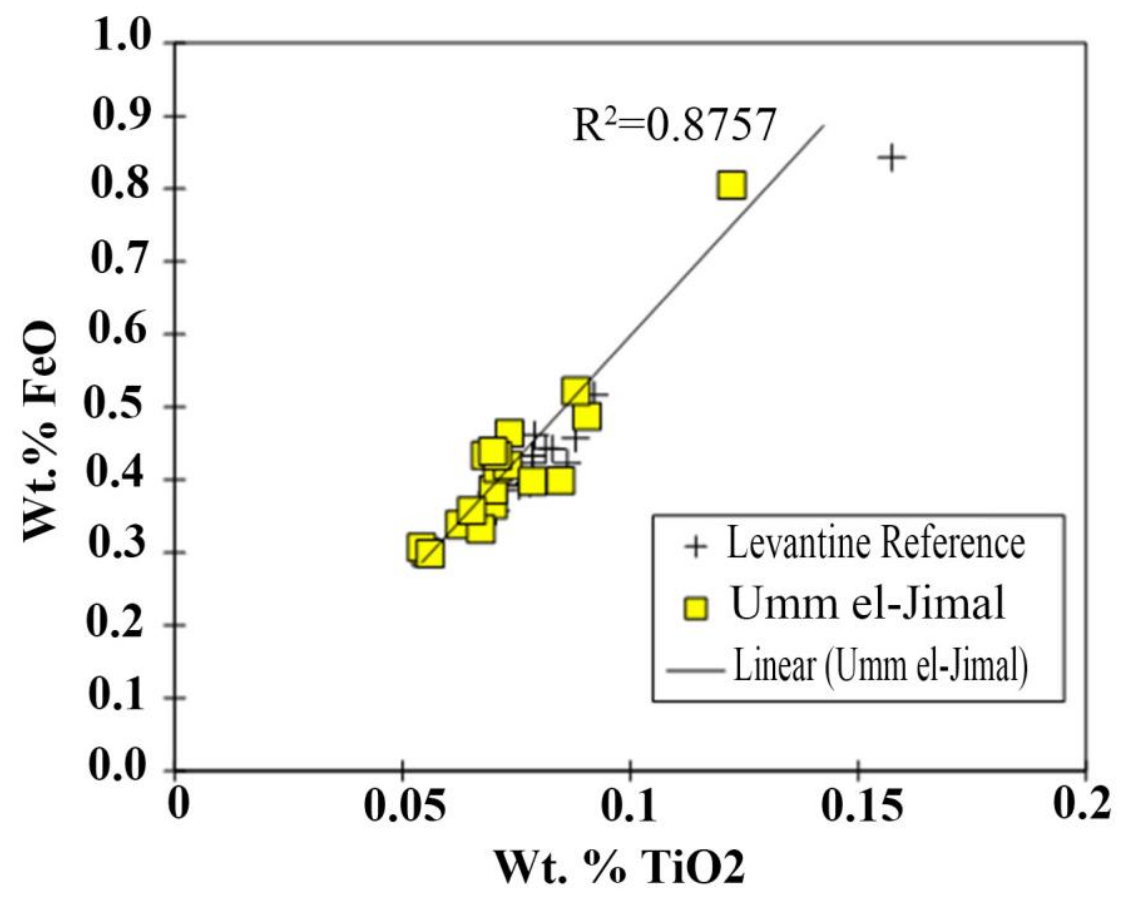

Fig. 3. Correlation of iron and titanium oxides, showing that the Umm el Jimal glass lies on the same trend as reference materials from the furnaces of Apollonia-Arsuf and Bet Eli'ezer (Hadera) on the Syro-Palestinian coast. Reference compositions: unpublished LA-ICP-MS data of Freestone.

The glass from the coastal plain of Palestine was termed "Levantine" by $[12,15]$ who defined two groups, Levantine I and Levantine II. Levantine I was an artificially constructed "Byzantine" group comprising late Roman (fourth century) glass from the production site of Jalame [9] and various other sites, including a known primary production centre ApolloniaArsuf which operated in late Byzantine times $\left(6^{\text {th }}-7^{\text {th }}\right.$ centuries $)$. The second group, Levantine II, consisted only of raw glass from the primary production furnaces at Bet Eli'ezer (Hadera) which at the time were considered late Byzantine-early Islamic, but which recent analytical work appears to place firmly in the Umayyad period [16]. In fact, the accumulation of significantly more analyses from Apollonia-Arsuf [13,14] shows that the products of the furnaces there differ from the fourth century material from Jalame.

The bi-plot of $\mathrm{CaO}$ vs $\mathrm{Al}_{2} \mathrm{O}_{3}$ in (Fig. 2) shows that there is a change in the composition of these two components from $4^{\text {th }}$ century Jalame, through 6- $7^{\text {th }}$ century Apollonia-Arsuf, to 7$8^{\text {th }}$ century Bet Eli'ezer (Hadera), moving from the upper left to lower right. The plot shows a gradual decrease in lime $(\mathrm{CaO})$ and increase in alumina $\left(\mathrm{Al}_{2} \mathrm{O}_{3}\right)$. It is therefore clear that it is no longer appropriate to group Jalame and Apollonia-Arsuf products in a single category. 
Rather than using the terms "Levantine I" and "Levantine II", Syro-Palestinian glasses should, where possible, be attributed to a specific production centre, or the regional term "Levantine" used as a general attribution.

The Umm el-Jimal glass has high alumina (c. 3\%), low soda (c. 12-15\%) which particularly characterize Levantine glass of the late Roman-Umayyad periods (Table 2, Fig. 2). Furthermore, there is a strong correlation between iron and titanium oxides which yields a trend matching reference samples from Levantine tank furnaces (Fig. 3). There is therefore little doubt that the Umm el-Jimal glass originated in the Levantine coastal strip. From (Fig. 2) it is observed that the majority of the Umm el-Jimal glass appears to relate to the Apollonia-Arsuf group ("Levantine I") as might be expected from the Byzantine date (AD324-636) assigned to this assemblage. Apollonia-Arsuf products have a composition characterized by around $16 \%$ soda, $8 \%$ lime, $3 \%$ alumina and $70 \%$ silica [13]. However, a number of samples appear to relate more to Bet Eli'ezer (Hadera) group (Levantine II) that has a composition that is characterized by around 12\% soda, $7 \%$ lime, 3.3 alumina and $75 \%$ silica [12,16]. A more effective discriminator between glass from Apollonia-Arsuf and that from Bet Eli'ezer (Hadera) involves comparing the ratios $\mathrm{Na}_{2} \mathrm{O} / \mathrm{SiO}_{2}$ and $\mathrm{CaO} / \mathrm{Al}_{2} \mathrm{O}_{3}$, as in (Fig. 4). Here we have divided the Umm el Jimal glass into two groups, high- and low-CaO, which more-or-less correspond to the Apollonia-Arsuf and Bet Eli'ezer (Hadera) type glasses.

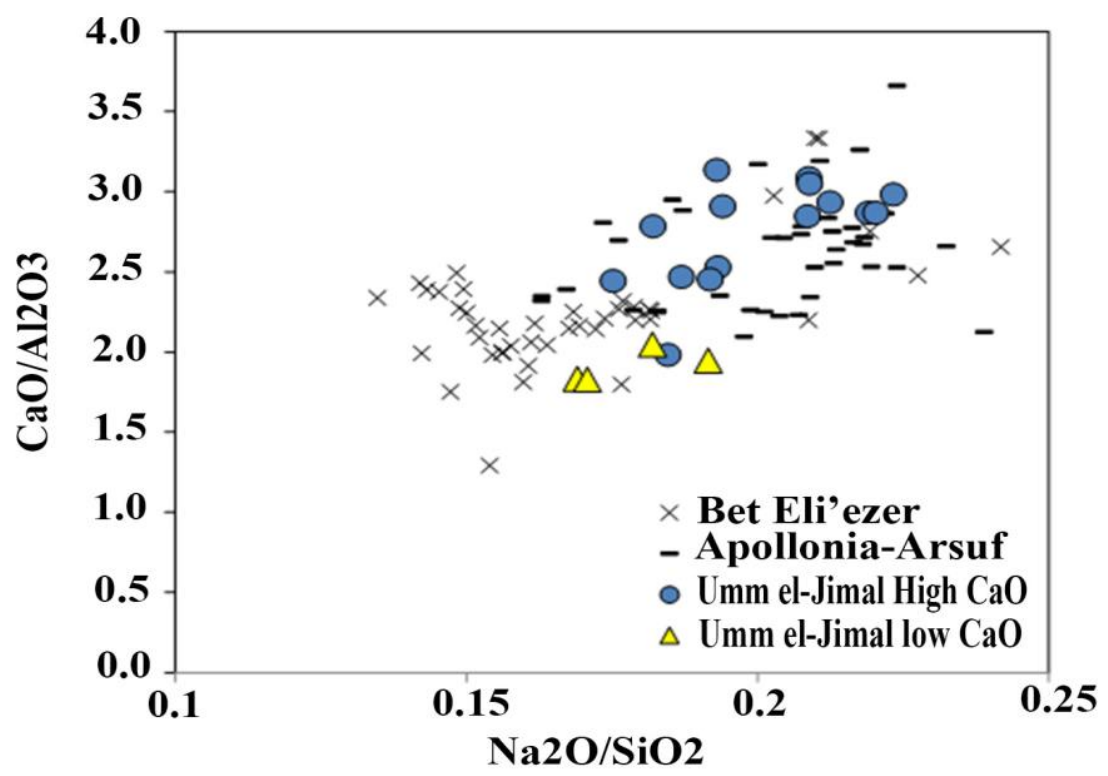

Fig. 4. Comparison of Umm el-Jimal samples with glass from the primary production centres at Bet Eli'ezer (Hadera) and Apollonia-Arsuf. 
We cannot ascribe the low-CaO glasses to Bet Eli'ezer (Hadera) with full confidence at this point; there remains overlap between the reference groups, the number of reference samples remains limited, and there may be other Levantine production centres operative in the period which have not yet been identified [cf. 16]. However, it does raise the possibility that some of the glasses in our sample (Table 1) may be Umayyad, rather than Byzantine. This is also suggested by the presence of a single plant ash glass in the group, as plant ash glass is not characteristic of the Byzantine Levant, the transition from natron to plant ash flux having occurred in the ninth century [eg. 7,17]. Similar results are obtained by utilising the flowchart of Brems and Degryse [18], which also determines samples 5,6,7,18 as "Levantine II" i.e. from Bet Eli' ezer (Hadera).

The presence of some Umayyad glass composition in the archaeological assemblage suggests the reuse of the churches during the Umayyad period or an intrusion of these samples due mixing of archaeological layers. Furthermore, several samples are from Saint Maria church (Table 1) which, on the basis of ceramic evidence, was re-used during the Umayyad period.
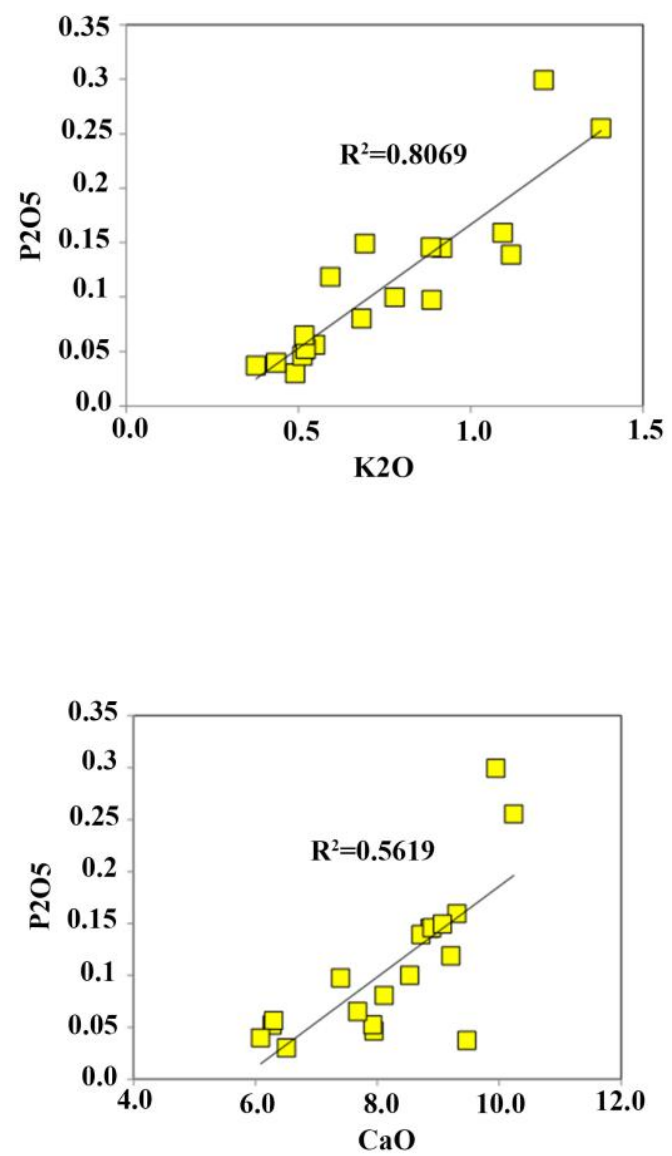

Fig. 5. Correlations between phosphate and potash (up) phosphate and lime (down) in the natron glasses, suggesting contamination by fuel ash. 


\subsection{Recycling}

The Umm el Jimal natron glasses show strong correlations between $\mathrm{K}_{2} \mathrm{O}, \mathrm{CaO}$ and $\mathrm{P}_{2} \mathrm{O}_{5}$ (Fig. 5). This is likely to represent contamination of the glass in the furnace by fuel ash and fuel ash vapour $[19,20,21]$.

There is an increasing agreement that this contamination is particularly characteristic of recycled glass, where the interaction of glass and fuel may be increased by repeated remelting and/or the use of small and less efficient furnaces in workshops which work mainly with recycled materials [e.g. 22,23,24].

Other indicators of recycling include contamination by colourants such as copper and lead, which are incorporated when small amounts of coloured glass are included in the recycled batch $[25,26]$ and also iron, which is incorporated partly as the oxidised scale which forms on the end of the iron blowpipe used to manufacture the glass [24]. Finally, contamination by decolourisers, manganese or antimony, may occur when decolourised glass is recycled into a batch comprising largely naturally coloured material. No antimony was detected (above $0.02 \%$ ) as a decolorant in any of the samples examined here. Furthermore, most (16 samples) have very low concentrations of $\mathrm{MnO}$, close to or below the detection limit of c. $0.02 \%$. The natural level of $\mathrm{MnO}$ in glassmaking sands and in samples from primary tank furnaces is about this level $[16,18]$. Three samples have $\mathrm{MnO}$ concentrations between 0.1 and $0.6 \%$ which, while significant, is still quite low to be considered an effective decolorizing agent. These intermediate values might have been generated by the recycling of Mn-decolourised glass with glass which had not been decolourised. This is consistent with the findings of Foy et al. [27] who found that in their sample, after the fifth century Levantine glass was no longer decoloured using manganese. Table 2 indicates that the samples with elevated manganese also tend to have elevated $\mathrm{PbO}$ and $\mathrm{CuO}$, supporting the idea that they are recycled.

We have arranged the data table (Table 2) in a format to provide information which is diagnostic of recycling, which we term a Diagnostic Recycling Table (DRT). The analyses for the major, high- $\mathrm{CaO}$ group are arranged in descending order of $\mathrm{K}_{2} \mathrm{O}$. Components are highlighted where they exceed what we consider to be the "naturally occurring" background values of the glass components (i.e. those due to the glassmaking sand). These background thresholds were set conservatively and for our Levantine glasses (note that the thresholds will be different for other glass types such as HIMT) are taken as $0.6 \% \mathrm{~K} 2 \mathrm{O}, 0.6 \% \mathrm{MgO}, 0.1 \%$ $\mathrm{P} 2 \mathrm{O} 5,0.45 \% \mathrm{FeO}, 0.03 \% \mathrm{MnO}$, and the detection limits of $0.02 \%$ for $\mathrm{CuO}$ and $\mathrm{PbO}$. The 
thresholds are based upon the re-analysis using LA-ICP-MS of material directly from primary furnaces at Apollonia [12,] and Bet Eli'ezer (Hadera) [12, unpublished work of Freestone and Gratuze]. A particularly interesting characteristic brought out by Table 2 is that those samples which have elevated $\mathrm{Fe}, \mathrm{Mn}, \mathrm{Cu}$ and $\mathrm{Pb}$ oxides are among those which are most contaminated by $\mathrm{K}$ and $\mathrm{P}$ (Table 2), which supports the interpretation of the elevated potash and phosphate as the result of recycling. Furthermore, it suggests that the use of elevated ashrelated elements and transition metals together as indicators of recycling should be more reliable and robust than either approach alone [see also 23:176].

We also observe a weak inverse correlation between potash and chlorine in the high $\mathrm{CaO}$ group (Fig. 6). This is explicable in terms of the behaviour of these components in the glass working furnace. Potassium is vaporised from wood-ash at temperatures in excess of about $900^{\circ} \mathrm{C}[28]$ and this is likely to be responsible for a significant component of the

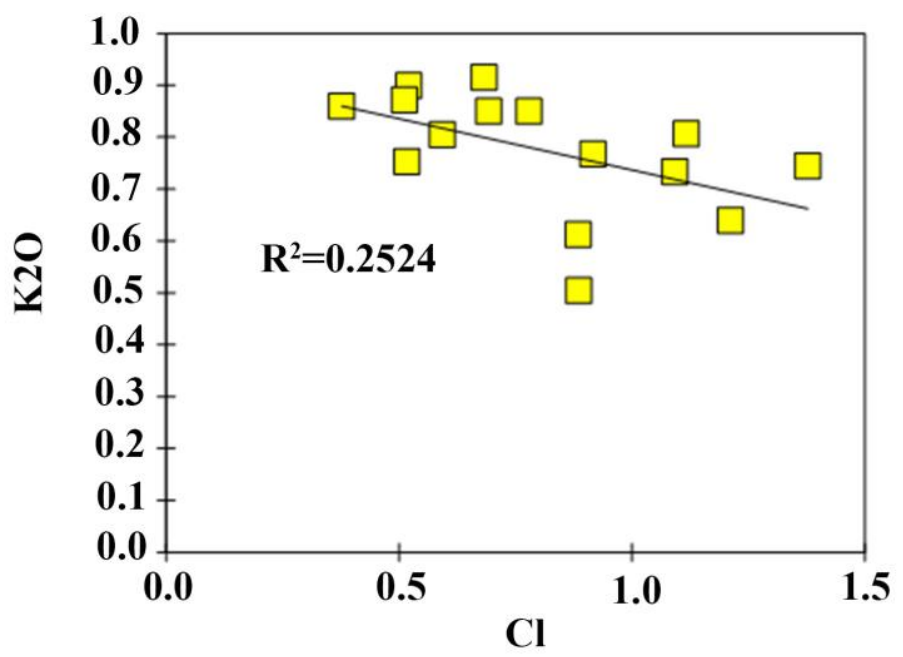

Fig. 6. Weak inverse correlation between potash and chlorine for glasses of the high $\mathrm{CaO}$ group.

contamination by this element in wood-fired furnaces, as opposed to direct contamination by ash particles, which is also likely to occur. Chlorine is a volatile, and prolonged or repeated melting of the glass is likely to result in a depletion of this element. Chlorine depletion and potash contamination are therefore both dependent upon the duration of contact between the surface of the glass and the furnace atmosphere at high temperatures, giving rise to the antipathetic relationship observed. 
Most of the high- $\mathrm{CaO}$ group of glass identified in this study therefore shows evidence of significant recycling. However, we do not observe this in the low-lime group, where concentrations of contaminants show no evidence of elevation (Table 2).

As mentioned above, elevated values of copper, iron, lead, zinc and tin in sample 15 most probably indicate another kind of recycling, the use of remnants of copper alloy and iron as a colourant. In fact, besides iron, the dark green color is most probably derived from the elevated level of copper [30].

\section{Discussion}

The attribution of the majority of the glasses to Apollonia-Arsuf/Levantine I type production is consistent with previous studies of Byzantine glass in northern Jordan. Alama [29] studied Roman-Byzantine-Early Islamic glass samples from Al-Fudien site in Al-Mafraq city about $20 \mathrm{~km}$ west Umm el-Jimal (see map) and attributed the Byzantine samples to the Levantine I and II groups. Abd-Allah [31] analyzed 20 late Roman and 20 early Byzantine glass samples from Beit-Ras archaeological site, north Jordan and showed that the early Byzantine glasses are of Levantine I group with averages of silica $70.65 \%$, soda $13.93 \%$, lime $8.25 \%$ and alumina $3.11 \%$. The results of Abd-Allah did not indicate a clear distinction between the chemical composition of the late Roman and the early Byzantine samples. Recently, [32] analyzed 8 glass samples from Gadara (Umm-Qais), northwest Jordan (see map). The samples showed averages of $\mathrm{Na}_{2} \mathrm{O}$ (14.79\%), $\mathrm{CaO}$ (10.15\%), and $\mathrm{Al}_{2} \mathrm{O}_{3}$ (3.34\%). The results show moderate-high percentages of alumina and lime, and indicate that the glasses are natron soda-lime-silica and of Levantine I group. Perhaps unsurprisingly, it appears that the glass supply in northern Jordan at this time was dominated by the glass made on the Levantine coast, Hadera is just $88.5 \mathrm{~km}$ from Irbid, and a similar situation also seems to have prevailed at Petra in the South [20, 33].

Less expected, given the proximity of the Levantine production sites, is the finding that most of the Apollonia-Arsuf type glass we have examined shows strong evidence for recycling, implying that the local vessel and window manufacturers frequently depended upon recycled glass rather than fresh material from the coast. The results of [20] suggest that a similar situation prevailed in the South. There are a number of possible explanations for this observation, and these need not be mutually exclusive. It could simply reflect a limited supply of fresh glass, or that the tank furnaces on the coast operated only sporadically. Alternatively, the raw glass may have been directed towards overseas or external markets, 
rather than internally. Whatever the reason, however, the apparent strong dependence upon recycled glass has socio-economic implications which merit further investigation.

Some relationship may be discerned between the archaeological contexts of the glass samples and their composition. We have indicated the various buildings (A - Cathedral; B - Double Church/Theophilus; C - Saint Maria Church; D - North Cemetery) in Table 1 along with the threshold between those glasses which show two or more indicators of recycling and those with no definite indicators. It can be seen that the glasses showing evidence of recycling are generally found in contexts $\mathrm{C}$ and $\mathrm{D}$, whereas the more pristine glasses occur in $\mathrm{A}$ and $\mathrm{B}$. In particular the low-CaO (Bet Eli'ezer (Hadera) type) glasses are found mainly in context $\mathrm{B}$, the Double Church. While the reasons for this are not entirely clear at present, we note that the glasses from the North Cemetery, context D, are from a sealed funerary context and definitely Byzantine. These glasses are therefore more likely to be relatively early in the sequence of the site, while the later Bet Eli'ezer (Hadera) glasses are from the Double Church and the Saint Maria Church.

\section{Conclusions}

The chemical analysis of the Byzantine glass samples from the Cathedral, the Double church (or Theophilus), the Saint Maria church (chapel) and the North cemetery of Umm el-Jimal showed a consistent glass-making technology. All of the samples (except sample 15) are soda-lime-silica glass where natron salts were used as a flux. The majority (15) of the samples belong to the Levantine I group, which appears to have been characteristic of the late Byzantine period, while a few samples are closer to Levantine II group which appears to have been predominantly Umayyad. The results indicate that Umm el-Jimal site utilized the glass types that were dominant in the region during the Byzantine and Umayyad periods and was therefore part of the major network of glass production and trade spread through the whole area of north Jordan. Most likely, secondary glass workshops for shaping glass artefacts existed in Umm el-Jimal and/or the major Decapolis sites of Jordan during the Roman and Byzantine times.

The basic aspect of this study is the re-enforcement of the evidence for recycling in the Byzantine period by an exceptionally wide range of recycling indicators, including ashderived elements, colourants and decolourants, chlorine and iron. This might suggest that the supply of fresh glass produced on the coast of Palestine was restricted at this time.

\section{Acknowledgements}


This work is based upon a thesis submitted for the MA degree at the Department of Archaeology, Yarmouk University by the second author Shatha Al-Mustafa. The authors acknowledge the permission to collect samples and support of the Department of Antiquities of Jordan. We thank Dr Harriet White and Mr Kevin Reeves for their help with sample preparation and analysis.

\section{References}

[1] S. Ilani, Y. Harlavan, K. Tarawneh, I. Rabba, R. Weinberger, K. Ibrahim, S.G. Peltz, G. Steinitz, New K-Ar ages of basalts from the Harrat Asham volcanic field in Jordan: Implications for the span and duration of upper mantle upwelling beneath the western Arabian plate, Geology 29 (2001) 171-174.

[2] H.C. Butler, Umm idj-Djimal. In Ancient Architecture in Syria, Publications of the Princeton University Archaeological Expedition to Syria, Division II-III, Brill, Leiden, 1913.

[3] B. De Vries, Umm el-Jimal: A frontier town and its landscape in northern Jordan, volume 1, fieldwork 1972-1981, J. Roman Archaeol. Supp. 26, Portsmouth, England. 1998

[4] R.H. Brill, Chemical Analyses of Early Glasses, The Corning Museum of Glass, New York, 1999.

[5] E. P. Vicenzi, S. Eggins, A. Logan, \& R. Wysoczanski, 2002. Microbeam characterization of Corning archeological reference glasses: new additions to the Smithsonian microbeam standard collection. J. Res. Natl. Inst. Stan. 107 (2002) 719-727.

[6] B. Wagner, A. Nowak, E. Bulska, K. Hametner, D. Günther, Critical assessment of the elemental composition of Corning archeological reference glasses by LA-ICP-MS. Anal Bioanal. Chem. 402 (2012) 1667-1677.

[7] J. Henderson, Tradition and experiment in first millennium A.D. glass production - The emergence of early Islamic glass technology in late antiquity, Accounts Chem. Res. 35 (2002) 594-602.

[8] A. Silvestri, G. Molin, G. Salviulo, Roman and medieval glass from the Italian area: bulk characterization and relationships with production technologies, Archaeometry 47 (2005) 797-816.

[9] I. C. Freestone, Glass production in Late Antiquity and the Early Islamic period: a geochemical perspective, in: M. Maggetti, B. Messiga (Eds.), Geomaterials in Cultural Heritage 257, Geological Society of London Special Publication, London, 2006, pp. 201-216.

[10] R.H. Brill, The chemical interpretation of the texts, in: A.L. Oppenheim, R.H. Brill, D. Barag, A. von Saldern (Eds.) Glass and Glassmaking in Ancient Mesopotamia, Corning Museum of Glass, New York, 1970, pp. 105-128.

[11] R.H. Brill, Scientific investigations of the Jalame glass and related finds, in: G.D. Wienberg (Eds.), Excavations at Jalame, site of a glass factory in late Roman Palestine. University of Missouri Press, Columbia, 1988, pp. 257-293. 
[12] I.C. Freestone, Y. Gorin-Rosen, M.J. Hughes, Primary glass from Israel and the production of glass in the late antiquity and the early Islamic period, in: M.D. Nenna, (Ed.), La route du verre. Ateliers primaires et secondaires du second millénaire av. J.-C. au Moyen Âge, Travaux de la Maison de l'Orient Méditerranéen 33, Lyon, 2000, pp. 65-83.

[13] I.C Freestone, R.E. Jackson-Tal, O. Tal, Raw glass and the production of glass vessels at late Byzantine Apollonia-Arsuf, Israel, J. Glass Stud. 50 (2008) 67-80.

[14] O. Tal, R.E. Jackson-Tal, I.C. Freestone, New evidence of the production of raw glass at late Byzantine Apollonia-Arsuf, Israel, J. Glass Stud. 46 (2004) 51-66.

[15] I.C. Freestone, M. Ponting, M.J. Hughes, The origins of Byzantine glass from Maroni Petrera, Cyprus, Archaeometry 44 (2002) 257-272.

[16] I. C. Freestone, R. Jackson-Tal, O. Tal and I. Taxel, Glass Production at an Early Islamic Workshop in Tel Aviv, J. Archaeol. Sci. 62 (2015) 45-54.

[17] B. Gratuze, J.N. Barrandon, (1990). Islamic glass weights and stamps: analysis using nuclear techniques, Archaeometry, 32 (1990) 155-162.

[18] D. Brems, P. Degryse, Trace element analysis in provenancing Roman glassmaking, Archaeometry 56 (Suppl. 1) (2014) 116-136.

[19] S. Paynter, Experiments in the reconstruction of Roman wood-fired glass-working furnaces: waste products and their formation processes, J. Glass Stud. 50 (2008) 271-290.

[20] Th. Rehren, , F. Marii, , N. Schibille, , L. Stanford, C. Swan, Glass supply and circulation in early Byzantine southern Jordan, in: J. Drauscke, D. Keller (Eds.), Glass in Byzantium - Production, Usage, Analyses, RGZM 8, Mainz, 2010, pp. 65-82.

[21] O. Tal, R. Jackson-Tal, I. Freestone, Glass from a Late Byzantine secondary workshop at Ramla (South) Israel, J. Glass Stud. 50 (2008) 81-95.

[22] I.C. Freestone, The recycling and reuse of Roman glass: analytical approaches, J. Glass Stud. 57 (2015) 29-40.

[23] T. Rehren, M. Brüggler, Composition and production of late antique glass bowls type Helle. J. Archaeol. Sci.: Reports 3(2015) 171-180.

[24] N. Schibille, I.C. Freestone, Composition, production and procurement of glass at San Vincenzo al Volturno: An early Medieval Monastic Complex in southern Italy. Plos One 8(2013), e76479, doi:10.1371/journal.pone.0076479, 136.

[25] C.M. Jackson, From Roman to early medieval glasses. Many happy returns or a new birth? Annales du 13e Congrès de l'Association Internationale pour l'Histoire du Verre. Lochem, the Netherlands: AIHV, Lochem, 1996, pp. 289-302.

[26] I. Freestone, R. Greenwood, and Y. Gorin-Rosen, Byzantine and early Islamic glassmaking in the Eastern Mediterranean: production and distribution of primary glass, in: 
G. Kordan (Ed.), Hyalo - vitrum - glass:History, technology and conservation of glass and vitreous materials in the Hellenic World, $1^{\text {st }}$ International conference, 1-4 April 2001, Rhodes, Greece, 2002, pp. 167-174.

[27] D. Foy, M. Picon, M. Vichy, V. Thirion-Merle, Caractérisation des verres de la fin de l'Antiquité en Méditerranée occidentale : l'émergence de nouveaux courants commerciaux, in: D. Foy, M.D. Nenna (Eds.), Échanges et commerce du verre dans le monde antique, Monographies Instrumentum 24, Montagnac, 2003, pp. 41-86.

[28] M.K. Misra, K.W. Ragland, A.J. Baker, Wood ash composition as a function of furnace temperature, Biomass and Bioenerg 4 (1993) 103-116.

[29] E. Alama, Glass excavated from AL-Fudein archaeological site: A comparative and analytical study, Unbublished MA thesis, Yarmouk University, Jordan, 2011.

[30] M. S. Gill, Th. Rehren, The Intentional Use of Lead-tin Orange in Indian Islamic Glazes and Its Preliminary Characterization. Archaeometry 56(6) (2014):1009-1023.

[31] R. Abd-Allah, Chemical characterization and manufacturing technology of late Roman to early Byzantine glass from Beit Ras/Capitolias, Northern Jordan, J. Archaeol. Sci. 37 (8) 1866-1874.

[32] L. El-Khouri, Glass production in the Early Byzantine period (4th-7th Century) at Gadara (Umm Qais), Jordan, area W, 2011 season of excavation, Levant 46 (2014) 89-97.

[33] N. Schibille, F. Marii, Th. Rehren, Characterization and provenance of Late Antique window glass from the Petra church in Jordan. Archaeometry 50 (2008) 627-642.

[34] C. Meyer, Glass from the North Theater Byzantine Church and Soundings at Jerash, Jordan, 1982-1983, in: W.E. Rast, (Ed.), Preliminary Reports of ASOR-Sponsored Excavations 1982-85, BASOR Supplement 25, Johns Hopkins University Press, Baltimore, 1987, pp.175-222.

[35] N. Katsnelson, The glass finds from Bet She'an (Youth Hostel), 'Atiqot 77(2014): 23-57.

[36] G.D. Weinberg, S.M. Goldstein, The glass vessels, in: G.D. Weinberg, (Ed.), Excavations at Jalame, site of a glass factory in Late Roman Palestine, University of Missouri Press, Columbia, 1988, pp. 38-102.

[37] M. Khoury, Jerash glass corpus: Glass excavated in 1982-1983, by the Australian and British teams. Unbublished MA thesis, Yarmouk University, Jordan, 1995.

[38] E. Cohen, Roman, Byzantine and Umayyad glass, in Y. Hirschfield, G. Solr, (eds), Hammat Gader excavations 1979-1982, Israel exploration society, Jerusalem, 1997, Pp. 396431.

[39] M.S. Gill, Th. Rehren, The intentional use of lead-tin orange in Indian Islamic glazes and its preliminary characterization, Archaeometry56(2014):1009-1023. 
[40] N.L. Lapp, Ancient glass, in: N.L. Lapp, (ed.), The excavations at Araq el-Emir, Volume I, American Schools of Oriental Research 47: Massachusetts, 1983, pp.43-63.

[41] R.E. Jackson-Tal, The glass and small stone finds from a Roman tomb at 'Ein elSha'ara. 'Atiqot 73(2013): 53-65.

Table 1 Colour, age, location and brief description of Umm el-Jimal glass samples.

\begin{tabular}{|c|c|c|c|c|c|}
\hline Sample & Colour & Period & Location & Description & Parallels \\
\hline & Olive green & $\begin{array}{c}\text { Early } \\
\text { Byzantine }\end{array}$ & $\begin{array}{l}\text { North } \\
\text { Cemetery: } \\
\text { the first } \\
\text { tomb near } \\
\text { the fence }\end{array}$ & $\begin{array}{l}\text { A base of a } \\
\text { double } \\
\text { cosmetic tube }\end{array}$ & $\begin{array}{c}\text { [34] Meyer } \\
\text { (1987) fig. 7U; } \\
\text { [35] Katsnelson } \\
\text { (2014): Fig. 5:4; } \\
\text { [36] Weinberg } \\
\text { and Goldstein: } \\
\text { Fig. 4-37: 339- } \\
\text { 340. }\end{array}$ \\
\hline & Bluish green & Byzantine & $\begin{array}{l}\text { The } \\
\text { Cathedral, } \\
\text { Baptism } \\
\text { room, } \\
\text { near the } \\
\text { arch }\end{array}$ & $\begin{array}{c}\text { Fragments of } \\
\text { a body of a } \\
\text { bottle }\end{array}$ & \\
\hline & Bluish green & Byzantine & $\begin{array}{l}\text { The } \\
\text { Cathedral, } \\
\text { Baptism } \\
\text { room, } \\
\text { near the } \\
\text { arch }\end{array}$ & $\begin{array}{c}\text { An } \\
\text { incomplete } \\
\text { base of a cup }\end{array}$ & $\begin{array}{c}\text { [34] Meyer } \\
\text { (1987): Fig. } \\
\text { 8y,aa,bb,cc; [31] } \\
\text { El-Khouri 2014: } \\
\text { Fig. 5:6,7; [36] } \\
\text { Weinberg and } \\
\text { Goldstein: Fig. } \\
\text { 4-24: 187-193. }\end{array}$ \\
\hline & Light green & Byzantine & $\begin{array}{l}\text { The } \\
\text { Double } \\
\text { church- } \\
\text { the south } \\
\text { church }\end{array}$ & $\begin{array}{l}\text { An } \\
\text { incomplete } \\
\text { handle of a } \\
\text { bottle }\end{array}$ & $\begin{array}{c}\text { [37] Khoury } \\
\text { (1995): Plate } \\
\text { XLIII: } \\
\text { 336,359,972,365; } \\
\text { [34] Meyer } \\
\text { (1987): Fig.12:P; } \\
\text { [36] Weinberg } \\
\text { and Goldstein: } \\
\text { Fig. 4-30:257- } \\
\text { 258. }\end{array}$ \\
\hline & $\begin{array}{l}\text { White: White: } \\
\text { Transparent }\end{array}$ & $\begin{array}{c}\text { Byzantine } \\
- \\
-\end{array}$ & $\begin{array}{l}\text { The } \\
\text { Double } \\
\text { church- } \\
\text { the south } \\
\text { church }\end{array}$ & $\begin{array}{l}\text { An } \\
\text { incomplete } \\
\text { rim of a } \\
\text { bottle }\end{array}$ & $\begin{array}{c}\text { [38] Cohen } \\
\text { (1997): Plate } \\
\text { VIII:5,6,8. }\end{array}$ \\
\hline & Bluish green & Byzantine & $\begin{array}{l}\text { The } \\
\text { Double } \\
\text { church- } \\
\text { the south } \\
\text { church }\end{array}$ & $\begin{array}{c}\text { An } \\
\text { incomplete } \\
\text { rim of a } \\
\text { lamb, bowl, } \\
\text { bottle or a } \\
\text { cup with an } \\
\end{array}$ & $\begin{array}{c}\text { [34] Meyer } \\
\text { (1987): Fig. 6T; } \\
\text { [38] Cohen } \\
\text { (1997): Plate II: } \\
\text { 13,14; [36] } \\
\text { Weinberg and }\end{array}$ \\
\hline
\end{tabular}




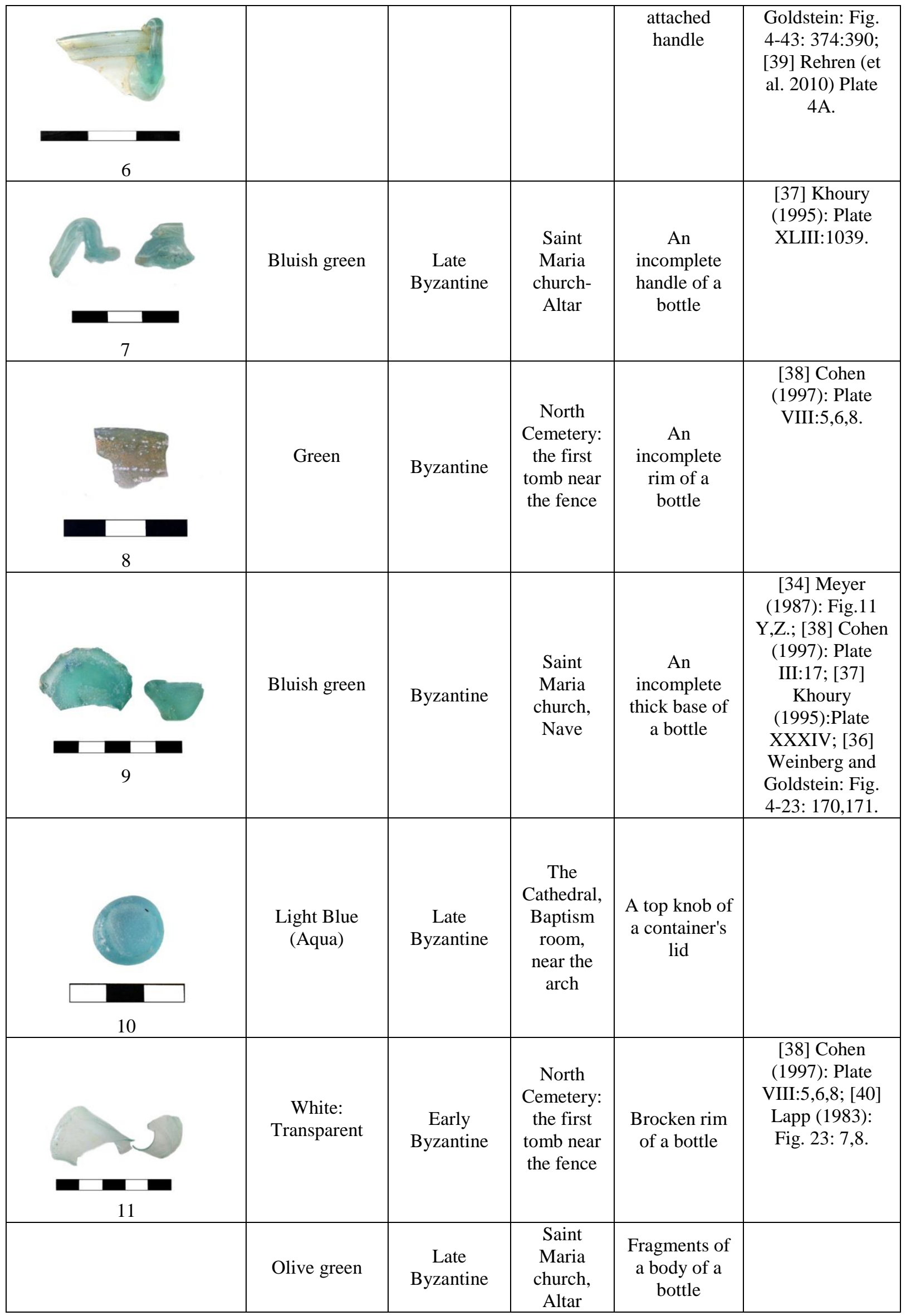




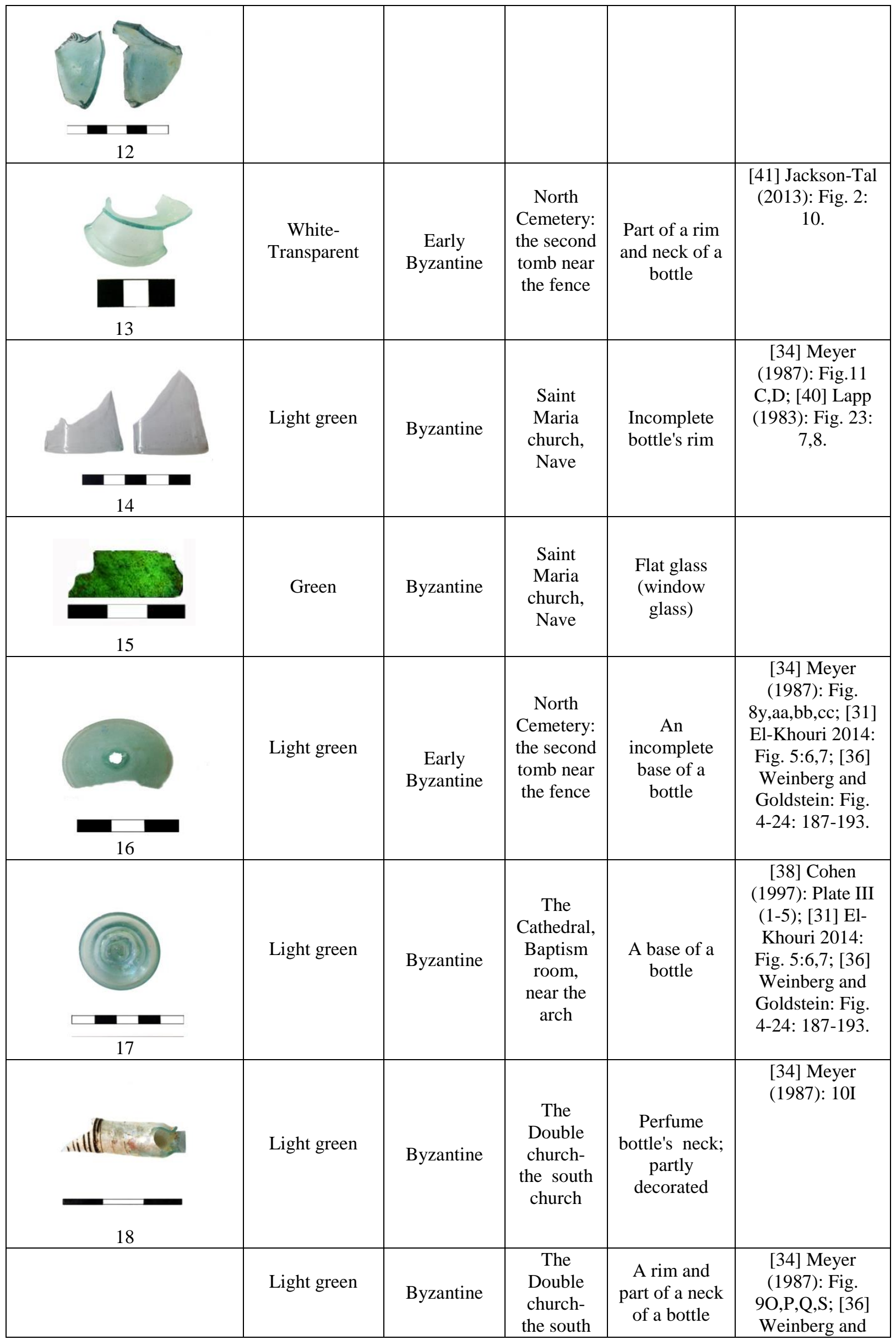




\begin{tabular}{|c|c|c|c|c|c|}
\hline $\begin{array}{r}0 \\
\\
\\
\end{array}$ & & & church & & $\begin{array}{l}\text { Goldstein: Fig. } \\
\text { 4-24: 187-193. }\end{array}$ \\
\hline - & $\begin{array}{l}\text { White- } \\
\text { transparent }\end{array}$ & Byzantine & $\begin{array}{l}\text { The } \\
\text { Double } \\
\text { church- } \\
\text { the south } \\
\text { church }\end{array}$ & $\begin{array}{c}\text { Fragments of } \\
\text { a body of a } \\
\text { bottle }\end{array}$ & \\
\hline
\end{tabular}


Table 2 Compositions of glasses from Umm el Jimal, presented in Diagnostic Recycling format (high CaO group arranged in descending $\mathrm{K}_{2} \mathrm{O}$ content; see text). Values italicized and on a grey background are likely to have been modified due to recycling processes. Values for Corning standards are from [4] except $*$ from [5] and $* *$ from [6].

\begin{tabular}{|c|c|c|c|c|c|c|c|c|c|c|c|c|c|c|c|c|c|c|c|c|c|c|c|}
\hline Group & Contex & xt Sample & $\mathrm{SiO}_{2}$ & $\mathrm{Na}_{2} \mathrm{O}$ & $\mathrm{CaO}$ & $\mathrm{K}_{2} \mathrm{O}$ & $\mathrm{MgO}$ & $\mathrm{P}_{2} \mathrm{O}_{5}$ & $\mathrm{Al}_{2} \mathrm{O}_{3}$ & $\mathrm{TiO}_{2}$ & $\mathrm{FeO}$ & $\mathrm{MnO}$ & $\mathrm{CuO}$ & $\mathrm{PbO}$ & $\mathrm{Cl}$ & $\mathrm{SO}_{3}$ & $\mathrm{Sb}_{2} \mathrm{O}_{5}$ & $\mathrm{CoO}$ & $\mathrm{SrO}$ & $\mathrm{BaO}$ & $\mathrm{ZnO}$ & $\mathrm{SnO}_{2}$ & Total \\
\hline Plant ash & C & 15 & 59.77 & 14.83 & 7.44 & 2.75 & 3.91 & 0.31 & 2.62 & 0.14 & 2.48 & 0.84 & 3.22 & 0.49 & 0.41 & 0.26 & $<0.02$ & $<0.02$ & .11 & 0.03 & 16 & 0.20 & 9.97 \\
\hline High $\mathrm{CaO}$ & D & 8 & 68.63 & 3.24 & 10.24 & 1.38 & 0.83 & 0.26 & 3.27 & .09 & 0.52 & 0.03 & 0.02 & 0.02 & 0.74 & 0.04 & $<0.02$ & $<0.02$ & 0.12 & 0.04 & $<0.02$ & $<0.02$ & 9.44 \\
\hline High $\mathrm{CaO}$ & D & 1 & 68.38 & 14.28 & 9.95 & 1.21 & 0.52 & 0.30 & 3.23 & 0.08 & 0.40 & $<0.02$ & $<0.02$ & $<0.02$ & 0.64 & 0.08 & $<0.02$ & $<0.02$ & 0.10 & 0.02 & $<0.02$ & $<0.02$ & 99.19 \\
\hline High $\mathrm{CaO}$ & A & 17 & 68.74 & 15.35 & 8.72 & 1.12 & 0.49 & 0.14 & 2.92 & 0.07 & 0.37 & 0.35 & 0.03 & $<0.02$ & 0.81 & 0.13 & $<0.02$ & $<0.02$ & 0.13 & 0.03 & $<0.02$ & $<0.02$ & 99.38 \\
\hline $\mathrm{High} \mathrm{CaO}$ & B & 19 & 68.27 & 14.95 & 9.31 & 1.09 & 0.68 & 0.16 & 3.25 & 0.07 & 0.43 & 0.08 & 0.02 & 0.07 & 0.73 & 0.11 & $<0.02$ & $<0.02$ & 0.10 & 0.03 & $<0.02$ & $<0.02$ & 99.35 \\
\hline $\mathrm{High} \mathrm{CaO}$ & C & 9 & 69.29 & 14.48 & 8.86 & 0.92 & 0.68 & 0.15 & 2.91 & 0.07 & 0.46 & 0.58 & $<0.02$ & 0.03 & 0.77 & 0.12 & $<0.02$ & $<0.02$ & 0.11 & 0.04 & $<0.02$ & $<0.02$ & 99.48 \\
\hline High $\mathrm{CaO}$ & C & 12 & 71.58 & 13.22 & 7.40 & 0.89 & 0.97 & 0.10 & 3.73 & 0.12 & 0.80 & 0.10 & 0.08 & 0.04 & 0.50 & 0.13 & $<0.02$ & $<0.02$ & 0.09 & 0.03 & $<0.02$ & $<0.02$ & 99.80 \\
\hline High $\mathrm{CaO}$ & D & 13 & 71.59 & 13.03 & 8.90 & 0.89 & 0.64 & 0.15 & 3.20 & 0.09 & 0.49 & 0.03 & $<0.02$ & $<0.02$ & 0.61 & 0.14 & $<0.02$ & $<0.02$ & 0.11 & 0.02 & $<0.02$ & $<0.02$ & 99.88 \\
\hline $\mathrm{High} \mathrm{CaO}$ & B & 4 & 69.72 & 15.36 & 8.53 & 0.78 & 0.51 & 0.10 & 2.97 & 0.06 & 0.34 & 0.02 & $<0.02$ & $<0.02$ & 0.85 & 0.19 & $<0.02$ & $<0.02$ & 0.09 & 0.03 & $<0.02$ & $<0.02$ & 99.56 \\
\hline High $\mathrm{CaO}$ & D & 16 & 69.74 & 14.55 & 9.07 & 0.69 & 0.56 & 0.15 & 3.19 & 0.07 & 0.42 & 0.02 & $<0.02$ & $<0.02$ & 0.85 & 0.10 & $<0.02$ & $<0.02$ & 0.10 & 0.03 & $<0.02$ & $<0.02$ & 9.55 \\
\hline $\mathrm{High} \mathrm{CaO}$ & C & 14 & 71.63 & 13.84 & 8.11 & 0.68 & 0.53 & 0.08 & 3.21 & 0.07 & 0.43 & $<0.02$ & $<0.02$ & $<0.02$ & 0.92 & 0.05 & $<0.02$ & $<0.02$ & 0.12 & 0.03 & $<0.02$ & $<0.02$ & 99.70 \\
\hline High $\mathrm{CaO}$ & $\mathrm{D}$ & 11 & 69.73 & 14.81 & 9.21 & 0.59 & 0.61 & 0.12 & 3.14 & 0.07 & 0.44 & $<0.02$ & $<0.02$ & $<0.02$ & 0.80 & .08 & $<0.02$ & $<0.02$ & .10 & 0.02 & $<0.02$ & 0.02 & 9.73 \\
\hline \multicolumn{24}{|c|}{ Evidence of significant recycling observable above this row } \\
\hline High $\mathrm{CaO}$ & A & 2 & 71.95 & 13.80 & 7.93 & 0.52 & 0.48 & 0.05 & 3.23 & 0.05 & 0.31 & $<0.02$ & $<0.02$ & $<0.02$ & 0.90 & 0.06 & $<0.02$ & $<0.02$ & 0.14 & 0.02 & $<0.02$ & $<0.02$ & 99.44 \\
\hline High $\mathrm{CaO}$ & A & 3 & 73.29 & 12.84 & 7.68 & 0.52 & 0.47 & 0.07 & 3.14 & 0.06 & 0.30 & $<0.02$ & $<0.02$ & $<0.02$ & 0.75 & 0.07 & $<0.02$ & $<0.02$ & 0.10 & 0.03 & $<0.02$ & $<0.02$ & 99.31 \\
\hline High $\mathrm{CaO}$ & B & 20 & 72.30 & 13.51 & 7.95 & 0.51 & 0.49 & 0.05 & 3.22 & 0.06 & 0.30 & $<0.02$ & $<0.02$ & $<0.02$ & 0.87 & 0.06 & $<0.02$ & $<0.02$ & 0.13 & 0.02 & $<0.02$ & $<0.02$ & 99.46 \\
\hline High $\mathrm{CaO}$ & A & 10 & 70.41 & 13.66 & 9.47 & 0.38 & 0.62 & 0.04 & 3.26 & 0.07 & 0.33 & 0.02 & $<0.02$ & $<0.02$ & 0.86 & 0.12 & $<0.02$ & $<0.02$ & 0.12 & 0.02 & $<0.02$ & $<0.02$ & 99.36 \\
\hline Low CaO & B & 5 & 73.68 & 14.11 & 6.08 & 0.44 & 0.43 & 0.04 & 3.13 & 0.07 & 0.36 & $<0.02$ & $<0.02$ & $<0.02$ & 0.78 & & & $<0.02$ & 09 & 0.03 & & 0.02 & 99.34 \\
\hline Low $\mathrm{CaO}$ & B & 18 & 73.87 & 13.44 & 6.51 & 0.49 & 0.44 & 0.03 & 3.18 & 0.07 & 0.39 & 0.02 & $<0.02$ & $<0.02$ & 0.82 & 0.08 & $<0.02$ & $<0.02$ & 0.10 & 0.03 & $<0.02$ & $<0.02$ & 99.47 \\
\hline Low $\mathrm{CaO}$ & B & 6 & 74.61 & 12.61 & 6.27 & 0.52 & 0.43 & 0.05 & 3.43 & 0.08 & 0.40 & 0.02 & $<0.02$ & $<0.02$ & 0.64 & 0.07 & $<0.02$ & $<0.02$ & 0.12 & 0.03 & $<0.02$ & $<0.02$ & 99.27 \\
\hline \multirow[t]{5}{*}{ Low $\mathrm{CaO}$} & C & 7 & 74.76 & 12.77 & 6.30 & 0.55 & 0.42 & 0.06 & 3.45 & 0.07 & 0.42 & 0.02 & $<0.02$ & $<0.02$ & 0.65 & 0.08 & $<0.02$ & $<0.02$ & 0.12 & 0.03 & $<0.02$ & $<0.02$ & 99.68 \\
\hline & Cornir & $g$ A Given & 66.56 & 14.30 & 5.03 & 2.87 & 2.66 & 0.13 & 1.00 & 0.79 & 0.98 & 1.00 & 1.17 & $0.07^{* *}$ & 0.10 & $0.13^{*}$ & 1.75 & 0.17 & 0.10 & 0.56 & 0.04 & 0.19 & \\
\hline & Averag & ge 10 ana & 66.24 & 14.47 & 4.94 & 2.88 & 2.59 & 0.12 & 0.98 & 0.71 & 0.96 & 1.03 & 1.18 & 0.07 & 0.09 & 0.16 & 1.70 & 0.17 & 0.16 & 0.50 & 0.04 & 0.20 & 99.19 \\
\hline & Corning & $g B$ given & 61.55 & 17.00 & 8.56 & 1.00 & 1.03 & 0.82 & 4.36 & 0.09 & 0.31 & 0.25 & 2.66 & $0.5^{*}$ & 0.20 & $0.45^{*}$ & 0.46 & 0.05 & 0.019 & 0.12 & 0.19 & 0.04 & \\
\hline & Averag & ge 10 ana & 61.66 & 17.09 & 8.59 & 1.07 & 1.00 & 0.86 & 4.50 & 0.10 & 0.30 & 0.25 & 2.66 & 0.46 & 0.16 & 0.58 & 0.38 & 0.04 & 0.10 & 0.09 & 0.16 & 0.02 & 100.10 \\
\hline
\end{tabular}

